\title{
DIGITALISATION OF SHOP-FLOOR OPERATIONS IN THE SOUTH AFRICAN TOOL, DIE, AND MOULD- MAKING INDUSTRY
}

\author{
M.T. Dewa ${ }^{1 * \#}$, A.F. van der Merwe ${ }^{1}$ \& S. Matope ${ }^{1}$
}

\section{ARTICLE INFO}

\begin{tabular}{lr}
$\begin{array}{l}\text { Article details } \\
\text { Submitted by authors }\end{array}$ & 12 Jan 2018 \\
$\begin{array}{l}\text { Accepted for publication } \\
\text { Available online }\end{array}$ & 15 Jul 2018 \\
& 31 Aug 2018 \\
\hline $\begin{array}{l}\text { Contact details } \\
\text { Corresponding author }\end{array}$ & $\begin{array}{l}\text { 17628598@sun.ac.za } \\
\text { Author affiliations } \\
\text { Department of Industrial } \\
\text { Engineering, Stellenbosch } \\
\text { University, South Africa }\end{array}$ \\
\# $\begin{array}{l}\text { Author was enrolled for a PhD in } \\
\text { the Department of Industrial }\end{array}$ \\
$\quad \begin{array}{l}\text { Engineering, Stellenbosch } \\
\text { University, South Africa }\end{array}$
\end{tabular}

DOI

http://dx.doi.org/10.7166/29-2-1899

\section{ABSTRACT}

Digitalisation has been advocated as a possible strategy to improve the competitiveness of tool, die, and mould-making (TDM) companies in the $21^{\text {st }}$ century. The recent rise of digital technologies, such as Internet of Things devices, now makes digitalisation an achievable reality. This paper focuses on the digitalisation of shop-floor operations in the South African TDM industry through the development of a novel mobile data collection (MDC) tool known as a shop-floor management system (SMS). The developed SMS was deployed to, and validated in, a selected tooling company for various products. The developed system improved the shop-floor's real-time data collection.

\section{OPSOMMING}

Digitalisering is voorgestel as ' $n$ moontlike strategie wat die mededingendheid van gereedskap- en gietvorming-maatskappye in die 21 ste eeu kan verbeter. Die onlangse opkoms van digitale tegnologie, soos Internet of Things-toestelle, maak nou digitalisering ' $n$ haalbare realiteit. Hierdie artikel fokus op die digitalisering van werkswinkelvloerbedrywighede in die SuidAfrikaanse TDM-bedryf deur die ontwikkeling van 'n nuwe mobiele data versameling instrument vir werkswinkelvloerbestuur. Die ontwikkelde stelsel is ontplooi tot, en gevalideer in, 'n geselekteerde gereedskapmaatskappy vir verskillende produkte. Die ontwikkelde stelsel het die werkswinkel-vloer se reële-tyd datainsameling verbeter.

\section{INTRODUCTION}

Tool, die, and mould (TDM) manufacturing has long been considered a key industrial sector, as it is the sole supplier of basic production equipment. Therefore, the TDM industry in South Africa is a critical support industry to the broader manufacturing industry, bridging the gap between product development and series production. This makes the sector a high value-adding constituent in the supply of manufactured products by being at the heart of component manufacturing and by forming the backbone of the manufacturing sector [1]. TDM firms have been traditionally known to consist of small, medium or micro-enterprises (SMMEs) that are usually family-owned businesses. The European tooling industry represents an annual turnover of approximately 13,000 million Euros, and consists of over 7,000 companies, 95 per cent of which are SMMEs [2]. Likewise, over 90 per cent of TDM firms in South Africa are small businesses in the range of SMMEs [3].

However, globalisation and the rapid growth in information communication technologies (ICT) have changed views about the way production is being done in the TDM sector. Gaining a competitive edge is no longer solely determined by product quality and lower costs: customers of the tooling industry grow more demanding and rapidly change their needs. There is a general consensus among researchers and industrialists that due date conformance and delivery reliability have also become major key success factors for successful firms in the TDM industry ([4]; [5]; [6]). 
Tool-making firms that align themselves with these current customer demands stand out on the market, and attract more clients than those that lag behind. A global survey conducted by Schuh, Pitsch, Kuhlmann and Stark [7] on the different tool-making firms (located in the 20 most important countries in the world of tooling) classified the different firms, based on their market share and competence levels, and using a 'world of tooling' radar, into four categories:

- $\quad$ Allstars: a cluster of TDM companies with a high tooling competence and a big market share.

- Established: a cluster of tool-making firms with a high tooling competence and a medium market size.

- $\quad$ Rookies: a cluster of tool-making firms with a medium tooling competence and a small market size.

- $\quad$ Rising stars: a cluster of tool-making firms with both a low tooling competence and a small market size [7].

The South African TDM sector was classified within the 'Rising star' category of the radar in the study, as depicted in Figure 1. This is mainly because recent results of the on-going benchmarking initiative in the South African TDM industry have shown that most firms struggle in the global market owing to intense external competition and internal shortcomings [8]. One of the identified challenges was that of poor organisational practices adopted by most observed TDM firms in South Africa. The organisational shortfalls of the South African TDM sector are a sign of poor business or operational practice on the shop-floor. According to Von Leipzig and Dimitrov [9], the results from the on-going benchmarking surveys clearly show that the initial and later stages of the tool production value stream are being neglected by South African TDM firms. In their analysis, Von Leipzig and Dimitrov [9] commented that the South African TDM sector is characterised by difficulties in data collection and manipulation. It is evident that the South African TDM sector has an intermediate potential to develop and improve its status and to become a globally recognised competitor - that is, attaining 'Allstar' status. The question remains: what can a South African TDM firm do to attain 'Allstar' status? This paper aims to answer this question by focusing specifically on how the South African TDM sector can overcome its data collection and manipulation shortcomings.

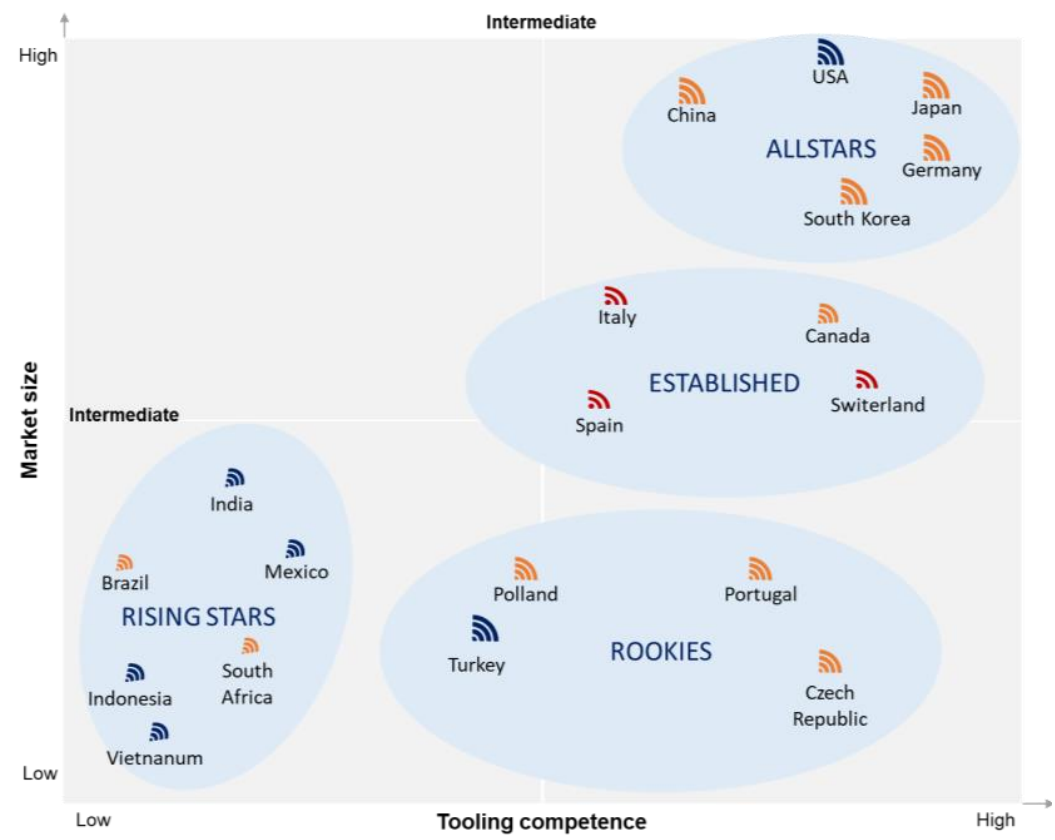

Developmental potential

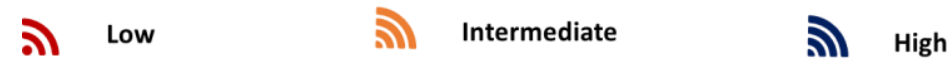

Figure 1: World of tooling radar [7] 
A study by Schuh, Pitsch, Salmen and Rittstieg [10] on the concept of 'fast forward tooling' identified nine critical success factors that tool-making firms can implement to improve their global competitive position (see Figure 2). One of the factors suggested in the work is that of 'digitalisation', which has the potential significantly to improve the competitiveness of a tooling enterprise, thereby becoming the basis for other success factors. The basis for digitalisation is the recording of data; and there is a lot of data one can find in a manufacturing environment. Hence, the concept enables the recording of information from manufacturing processes and from serial production. After the data is collected, it is processed into smart data, or information that is presented in a meaningful way for managers and decision-makers to make decisions. This permits the establishment of unique know-how or sustainable knowledge [10]. As a result, a company will possess expert knowledge that can be used for future decision-making, and may be commercialised. Thus the concept of digitalisation has the potential of addressing data collection and manipulation shortcomings.

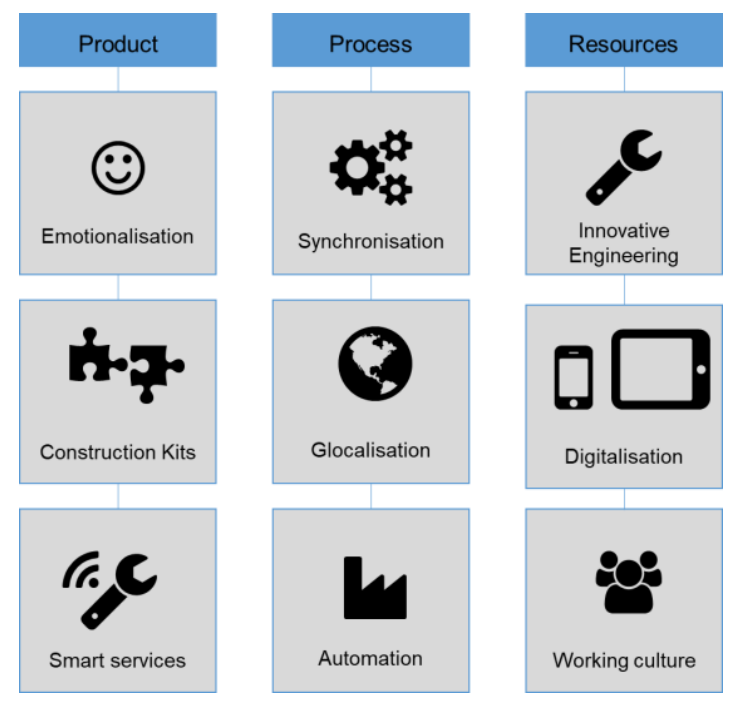

Figure 2: 'Fast forward tooling' success factors [10]

With the recent growth in ICT technology such as Internet of Things (IOT) devices, it is now possible to apply the concept of digitalisation, thus improving the flexibility, agility, efficiency, and productivity of operations in a tooling environment [11]. According to Business Insider estimates observed by Samuelson, Lanman and Pocek [12], by the year 2020 around 20 billion devices will be connected to the internet, with 40 per cent of these being loT devices, as shown in Figure 3.



Figure 3: Growth in loT devices [12] 
According to Schuh, Kuhlmann, Pitsch and Komorek [13], the loT devices will greatly impact the way toolmakers will perform production in the $21^{\text {st }}$ century. However, the application of loT or current ICT technology is yet to be fully explored in terms of its relevance in the digitalisation of shop-floor operations in the South African TDM industry. As a result, the potentials of digitalisation are yet to be comprehensively explored by South African tooling companies. This paper attempts to fill this gap by developing a system for the digital transformation of operations on the tool room shop-floor. A systematic method of process analysis, selection of appropriate technologies, design and development for the digital transformation is employed while accessing its applicability in the South African TDM context.

\section{LITERATURE REVIEW}

\subsection{Digitalisation}

In this section, the concept of digitalisation is further explored as a potential initiative to improve the competitiveness of TDM operations in the area of data collection. The benefits and perceived shortcomings of digitalisation are outlined. Mobile and cloud computing technologies are presented as supporting digitalisation and state-of-the-art research on digitalisation within the global tooling industry is shown. Then the relevance of this concept in the current tooling industry is justified.

\subsubsection{Concept of digitalisation}

Digitalisation can be viewed as the implementation of current modern ICT to improve production processes' efficiency and productivity. The concept has been promoted as having the potential significantly to improve the competitiveness of any manufacturing enterprise [14]. According to Stolterman and Fors [15], 'digitalisation', or 'digital transformation', refers to the changes associated with the application of digital technology to all aspects of human society [16]. The concept differs from 'digitisation', which refers to the conversion of analogue or manual processes to digital ones. Brennen and Kreiss [17] have defined digitalisation as "the adoption or increase in use of digital or computer technology by an organisation, industry or country". Unfortunately, the rate of adoption of digital technologies in the manufacturing sector has been slow, with most firms using a 'wait and see' approach [18]. However, the few companies that have implemented digital solutions have been able to tell stories of success. Thus tool-making firms ought to view digital solutions as an opportunity rather than as a threat [11].

Digitalisation is viewed as an on-going process rather than as a one-stop destination, as firms ought continually to evaluate what is worth digitalising. This is mainly because digital technologies evolve fast in a globalised world. To be successful, one has to keep up with current technological trends, and pilot small solutions incrementally to inspire workers while improving competitiveness. The concept of digitalisation has been found to apply to different scenarios and applications in the business world. The available literature records three different views of digitalisation: those at the process level, product level, and the supply chain level. In the process-level view of digitalisation, new digital tools are adopted to streamline business activities and processes by reducing manual steps [16], while the product-level view focuses on the ability to turn existing products or services into digital variants, thus offering a competitive advantage over other tangible products [19]. The supply-chain view of digitalisation focuses on the sole use of digital technologies to connect suppliers and customers, radically transforming business procedures through connectivity. Since this study focuses on the digitalisation of shop-floor operations in a tooling environment, only the processlevel view applies in this study. The main goal in process-level digitalisation is to ensure the realtime availability of information for decision-makers within an organisation [20].

\subsubsection{Benefits of digitalisation}

The digitalisation effort pays off in a lot of ways. Firstly, digitalisation improves process transparency, which is a key step to greater efficiency and profitability [21]. Anything that is recorded can easily be measured, tracked, and monitored. Secondly, since digitalisation ensures the processing of data into real-time information, often referred to as 'smart data', informed decisionmaking by production managers is supported. Eventually the productivity of the enterprise is considerably improved, since decisions can be made quickly, based on the readily available information [14]. The improved productivity will result in a substantial reduction in time spent by employees searching for information, as workers need to spend most of their time on activities that produce value. As a result, all employees become more efficient when working within an optimised process. Thirdly, with informed decisions made at all levels of the value chain, the costs associated 
with incorrect information and erroneous decisions are largely eliminated [22]. Moreover, business integration is significantly improved by digitalisation, helping firms to reduce greatly the time spent on interruptions while simultaneously enhancing their product or service quality [23]. This is crucial in the TDM industry, where there are no complete or standard solutions on the market for toolmaking firms. Thus each company is supposed to develop its own solutions, as they all have different applications and business context scenarios. Enterprise resource planning (ERP) solutions on the market usually do not fit well in a tooling environment, as they are offered with more modules than required. As a result, buying one is very expensive, and extra costs may be incurred in efforts to adapt the system to the business rules of the company using it. According to Schuh, Kuhlmann, Pitsch, and Komorek [13], digitalisation can aid in collaborative work within the tooling industry by ensuring seamless communication within value creation networks. Eventually the product's time-tomarket is improved while the focus on the customer is enhanced [24].

According to Schuh et al. [10], digitalisation in the context of tooling has to be adapted to industryspecific characteristics, which is why the industry-specific characteristics of a group need to be determined before selecting and implementing the appropriate digital technologies. In a study on establishing a framework for digitalisation in production firms, Krishnan, Pujari and Sarkar [25] outlined four dimensions that digitalisation can address in manufacturing: (1) The operational excellence of a production firm can be enhanced as productivity and efficiency across processes and functions grow. (2) A firm's agility or adaptation, its response to internal and external changes (disturbances), is improved. The dimensions of (3) innovation and (4) customer-centricity are also enhanced in a firm by digitalisation.

\subsubsection{Limitations of, and misconceptions about, digitalisation}

Although digitalisation has the potential to improve operations significantly, a few shortfalls need to be addressed. The internet is one of the central technologies in digitalisation. As a result, data security of sensitive information remains a challenge that is yet to be adequately resolved [26]. Furthermore, workers with low computer or digital literacy require sufficient training before they can implement or use any digital solutions [27]. These factors can slow down the acceptance or possible adoption of digital solutions. Digital transformation of business operations has often been perceived by business owners as a costly venture [28]. As a result, a majority of SMMEs do not consider trying to implement any new technology into their businesses. However, the cost of some digital devices has significantly reduced on the market, and do-it-yourself (DIY) open-source devices have opened new opportunities for innovative designs at little or no cost ([29]; [30]). Furthermore, digitalisation is often thought by some to be the same as 'automation'. According to Henriette, Feki and Boughzala [19], process automation is only one part of the entire digitalisation framework. This perception only focuses on the process-level view of digitalisation yet the concept also includes the product level and the supply chain level, as discussed earlier in section 2.1.1. As a result, another misconception workers usually have is that digitalisation may lead to the loss of jobs if manual processes are replaced by semi-automated methodologies. On the contrary: digitalisation should be viewed as a way of making processes better and more effective rather than replacing human labour [16]. A thorough understanding of the currently available digital technologies can assist in eliminating the above-mentioned misconceptions about digitalisation.

The next section will give a brief overview of some of the common classes of currently available digital technologies in the form of mobile devices and cloud computing platforms.

\subsubsection{Digitalisation through mobile devices and cloud computing platforms}

Mobile devices such as smartphones and tablets have become ubiquitous in everyday life [31]. These gadgets have become readily available at low prices, causing a growth in usage in our time. Modern smartphones have become programmable. They also come with a growing number of embedded sensors, such as a digital compass, accelerometer, gyroscope, GPS, microphone, and camera [32]. As a result, the range of data these devices can handle is enormous, including text messages, GPS, barcodes, QR-codes, pictures or images, audio, and video [18]. Furthermore, mobile devices can browse the internet, making them easily part of a global network of other objects. Mobile data can be accessed anywhere at any time in near-real time [33]. Mobile devices are well-suited for applications in which data collection is done repeatedly and conducted in a distributed way; and a large percentage of the data types collected are quantitative in nature [34].

According to Mell and Grance [35], cloud computing is a model for enabling ubiquitous, convenient, on-demand network access to a shared pool of configurable computing resources (e.g., networks, 
servers, storage, applications, and services) that can be rapidly provisioned and released with minimal management effort or service provider interaction. This model of technology is a broad field of study with numerous resources that allow the sharing of data over distributed systems. Google has the most commonly used cloud computing resources in the form of Google Drive [36]. Microsoft Azure is another commonly used platform for Windows users [37]. Cloud computing platforms have a wide usage in many domains, including business [38], healthcare, and manufacturing [39].

\subsubsection{State-of-the-art}

The implementation of current ICT in the TDM industry has been slow. Some researchers have successfully implemented solutions in TDM firms using current ICT. Efforts to create such information systems for the TDM sector are on-going, with examples from Choi, Shin, Choi and Lee [6], Hu, Zhou and Li [40], Silva, Roque and Almeida [41], and Li, Wang, San, and Seng [42], among others. An understanding of the TDM industry domain is therefore paramount before digitalisation can be fully implemented in the field.

The next section focuses on the research methodology adopted in developing a digital solution that suits the South African TDM sector.

\section{RESEARCH METHODOLOGY}

This section outlines the research design and methods used in the study. According to Krishnan et al. [25], a systematic approach, which involves analysis, design, development, and testing, is required to achieve the digital transformation of a business's operations. This design strategy entails analysis of the current state of an industry, identification of processes requiring improvement, and careful selection of appropriate technologies to bring about the digital transformation. Thus knowledge engineering and systems engineering methods were used in the study. Knowledge engineering was used to establish the industry-specific characteristics of the South African TDM sector by establishing the processes requiring digitalisation. The systems engineering methodology was employed for the development of the digital solution. This methodology involved selection of the appropriate digital technologies, and the design, development, testing, and validation of the final solution.

The systems engineering methodology was chosen because, according to Hoefler and Marm [43], this approach allows for a systematic route from problem definition to solution realisation, which results in a prototype being developed and tested. The agile approach of software development was used for the design and creation of the digital solution. According to Spataru [44], the agile approach simplifies the development process. This is because development is conducted incrementally for each module, unlike in the waterfall approach, which follows a hierarchy of long steps [44]. Firstly, a case study for a selected TDM company was used to test and validate the solution. At this stage, real-world scenarios and data were used to test the robustness of the system. Secondly, the available development platforms (software and hardware) were compared, using set criteria for the purpose of selecting the best platform. A questionnaire was designed to verify the selected technology, and decision matrices were developed, following Satterlee, E., McCullough, Dawson and Cheung [34], for the selection of the software and hardware.

The remaining stages, which involved designing, developing, and testing the system, were implemented in one selected company, as different tooling firms produce a wide range of products and services. As a result, the industry-specific characteristics vary from one company to another [10]. So case-study-specific data related to the selected firm was used.

After developing and testing a complete digital solution, the same company chosen during the design phase was used for the validation process, which followed three distinct phases:

- $\quad$ System preparation;

- $\quad$ System deployment; and

- $\quad$ Product selection and testing. 
This section outlines the major research findings of the study. The method of knowledge engineering was employed, with field experts from five different tool-making firms being were interviewed to obtain results on:

- Tool-room processes that could be significantly improved through digitalisation;

- $\quad$ Parameters for the identified processes; and

- Derivation of user needs and specifications.

The five experts who were visited were mainly from injection mould design and press metal tool production specialist firms within the Western Cape Province tool, die and mould-making (TDM) and plastics manufacturing industries. The mean number of employees for the observed population of companies was 10.4. The tooling expert from company D had the greatest amount of experience (40 years' experience in the tooling industry), as shown in Table 1. The average experience was found to be 28.6 years.

Table 1: Experts' experience in years

\begin{tabular}{|l|c|c|c|c|c|}
\hline $\begin{array}{l}\text { Expert from } \\
\text { company }\end{array}$ & A & B & C & D & E \\
\hline $\begin{array}{l}\text { Experience of the } \\
\text { expert (years) }\end{array}$ & 19 & 28 & 23 & 40 & 33 \\
\hline
\end{tabular}

\subsection{Selected processes}

The experts who were consulted were questioned about the tooling functions that greatly impacted the due date reliability or speed of a project. The experts all alluded to the following critical functions:

- Cost estimation

- $\quad$ Project management - planning, scheduling, and control

- Production

It was concluded, therefore, that improving the data collection in the domains of cost estimation, process planning, and production functions would significantly improve business operations in a tooling environment.

The cost estimation function was identified as crucial because research has shown that, in the mould-making industry, usually less than 10 per cent of all offers turn into orders ([45]; [46]; [47]; [48]). As a result, accurate and timely cost estimation before tool, die, and mould production is a key attribute for sustaining global competitiveness. Due to the skill shortages that the South African TDM industry has experienced, the majority of tool-making firms take a long time to quote for a job. Furthermore, results from benchmarking exercises at these firms have shown that the majority of the generated quotes lacked accuracy, due to the methods employed [45]. For effective and timely cost estimation, the parameters to be considered must be known, together with the decision heuristics to be followed. Furthermore, the project management of orders in a tooling environment is another complex task that requires great skill and expertise. This is mainly because operational disturbances such as rush orders or breakdowns can complicate the life of project managers. Carefully prepared process plans and schedules can easily become invalid, thus needing to be continually revised [49]. For a project to finish within the budgeted time, efficient project management techniques should be employed. All value-adding activities in a tool room need careful procedural conformance and great skill. As a result, administrative work on the shop floor can be a nightmare if it is not well-designed and well-managed. The time taken for each operation is a critical parameter, as it will help to give feedback on the progress of orders. Furthermore, knowledge of manufacturing task times serves as a valuable input during the cost estimation of the same job in the future.

After establishing these system functions, the key parameters for each function were derived. Since labour-related costs are the greatest contributor to the overall tool cost, monitoring and control of 
production time is crucial. One of the consulted experts indicated that over 60 per cent of the tool's costs are labour-related.

\subsection{Parameter and user derivation}

The system functions and parameters for the identified processes were also derived. Cost estimation, project planning, and production functions were deemed to be crucial in contributing to shop-floor management and to meeting delivery due dates. As a result, the main system users will be cost estimators, project managers, and artisans in a tool-making environment. The use case model generated in Figure 4, and the information in Table 2, summarise the key findings in the derivation process.

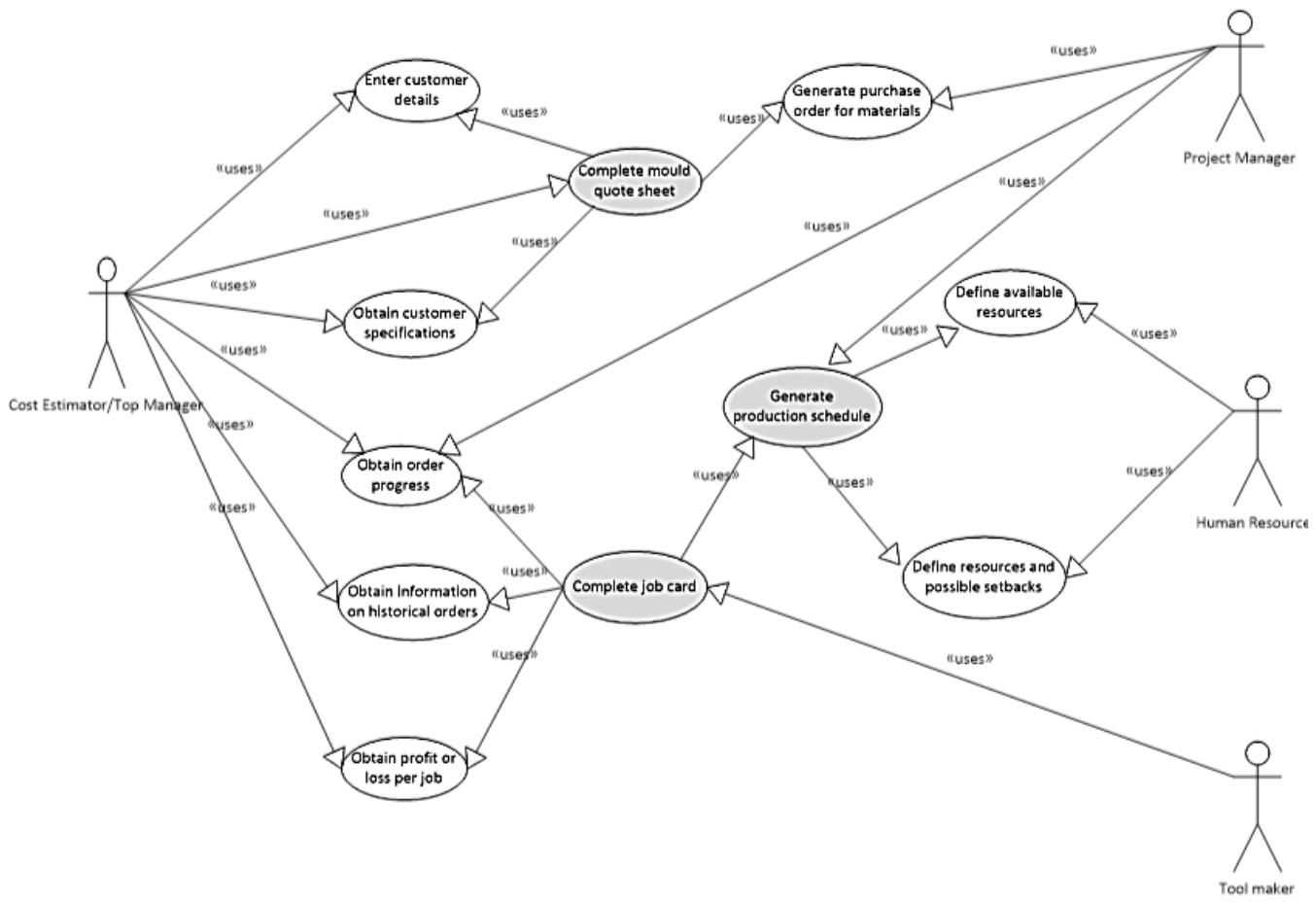

Figure 4: System use case model

The major system functions derived are highlighted in grey. Though the cost estimation, process planning, and production cases are the major functions, the human resources function plays a crucial role in defining the required operations and resources.

The database design and development was the first stage in setting up the system. The entity identification for each class was derived, and an entity relationship diagram (ERD) was developed, as shown in Figure 5. The 'Google Sheets' platform was used in developing the backend database for each of the tables. The mobile application for the system was developed using the AppSheet environment.

\subsection{Overview of shop-floor management system}

The overall system architecture and functionality is illustrated in Figure 6. With the use of webbased cloud computing platforms, the captured data can be collected in a distributed manner. This simplifies the methodology, as information can be accessed in real time at any place. Mobile devices speed up shop-floor data collection, reducing the costs incurred in preparing and printing paperbased documents. Furthermore, the conditional logic set in the mobile devices simplifies the enduser's collection process, thus reducing the effort involved in recording the data manually. 


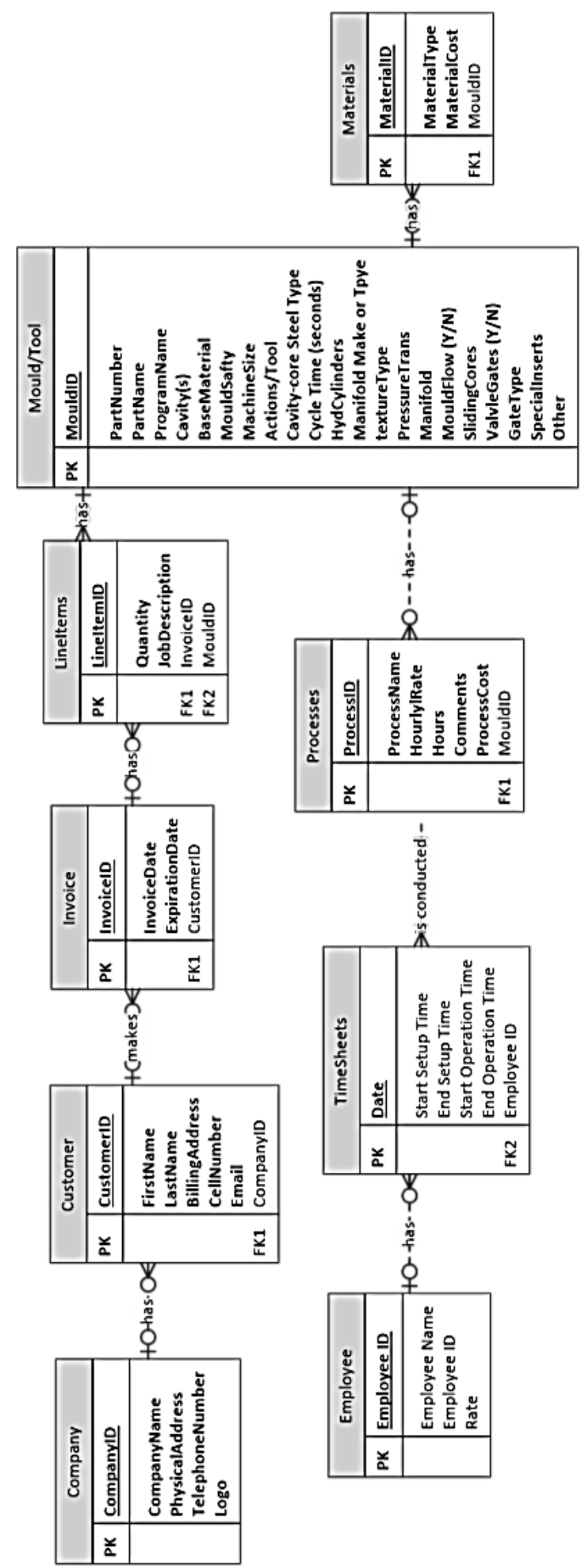

Figure 5: Entity relationship diagram (ERD) 
Table 2: System users, functions, and parameters

\begin{tabular}{|c|c|c|c|}
\hline Users & Functions & Parameters & Data for each parameter \\
\hline \multirow{3}{*}{ Cost estimator } & \multirow{3}{*}{$\begin{array}{l}\text { - Cost } \\
\text { estimation } \\
\text { - Quoting }\end{array}$} & - Labour costs & $\begin{array}{l}\text { Number of hours for: } \\
\text { - Data management } \\
\text { - Mould design } \\
\text { - Computer simulations } \\
\text { - Advanced engineering } \\
\text { - CNC machining } \\
\text { - General shop labour } \\
\text { - CMM parts }\end{array}$ \\
\hline & & - Material costs & $\begin{array}{l}\text { Material type and weight required } \\
\text { for: } \\
\text { - Mould base } \\
\text { - Copper (electrodes) } \\
\text { - Cavity core steel } \\
\text { - Components } \\
\text { - Texture } \\
\text { - Tooling (cutters and inserts) } \\
\text { - Sample material }\end{array}$ \\
\hline & & - Service costs & $\begin{array}{l}\text { Number of hours required for: } \\
\text { - Heat treating and plating } \\
\text { - Manifold hot-runner system }\end{array}$ \\
\hline \multirow[t]{3}{*}{ Project manager } & -Planning & $\begin{array}{l}\text { - Material types and } \\
\text { dimensions }\end{array}$ & $\begin{array}{l}\text { - Material types } \\
\text { - Length, width, and height of } \\
\text { material } \\
\text { - Mass required }\end{array}$ \\
\hline & -Purchasing & $\begin{array}{l}\text { - Supplier lists } \\
\text { - Supplier costs } \\
\text { - Contractors list } \\
\text { - Contractor costs }\end{array}$ & $\begin{array}{l}\text { - Price of all materials } \\
\text { - Prices of all services }\end{array}$ \\
\hline & - Scheduling & & $\begin{array}{l}\text { - Available resources - workers and } \\
\text { machines } \\
\text { - Available dates and times }\end{array}$ \\
\hline \multirow[t]{2}{*}{$\begin{array}{l}\text { Production } \\
\text { workers }\end{array}$} & \multirow[t]{2}{*}{-Manufacturing } & Value-added time & $\begin{array}{l}\text { - Set-up time } \\
\text { - Operation time }\end{array}$ \\
\hline & & Non-value added time & $\begin{array}{l}\text { - Set-up downtime } \\
\text { - Operation downtime } \\
\text { - Operational disturbance reason }\end{array}$ \\
\hline
\end{tabular}

The responses of the five experts (represented in Table 3 and Table 4 respectively) validated the need to use mobile and cloud-computing technologies during shop-floor operations in South African TDM firms.

The developed system was integrated with the tooling companies' existing Microsoft Excel spreadsheets.

Table 3: Existing capacity analysis

\begin{tabular}{|l|l|l|}
\hline Question & $\begin{array}{l}\text { Summary of responses from } \\
\text { experts }\end{array}$ & Implications \\
\hline $\begin{array}{l}\text { Availability of mobile devices } \\
\text { (smart phones, tablets, etc.) }\end{array}$ & $\begin{array}{l}\text { No. } \\
\text { However, most workers have } \\
\text { their own devices. }\end{array}$ & $\begin{array}{l}\text { If workers have their own mobile } \\
\text { devices, there may be no need to } \\
\text { invest in buying devices. }\end{array}$ \\
\hline $\begin{array}{l}\text { Availability of workers skilled in } \\
\text { the use of mobile devices and } \\
\text { having ICT expertise }\end{array}$ & $\begin{array}{l}\text { Yes. } \\
\text { Few workers in a tooling } \\
\text { environment are skilled in ICT. } \\
\text { Usually the tool designers are } \\
\text { good at using computer } \\
\text { technology (because they use } \\
\text { computers every day) }\end{array}$ & $\begin{array}{l}\text { There may be a need to train } \\
\text { workers how to use digital } \\
\text { technologies if they are introduced. }\end{array}$ \\
\hline
\end{tabular}




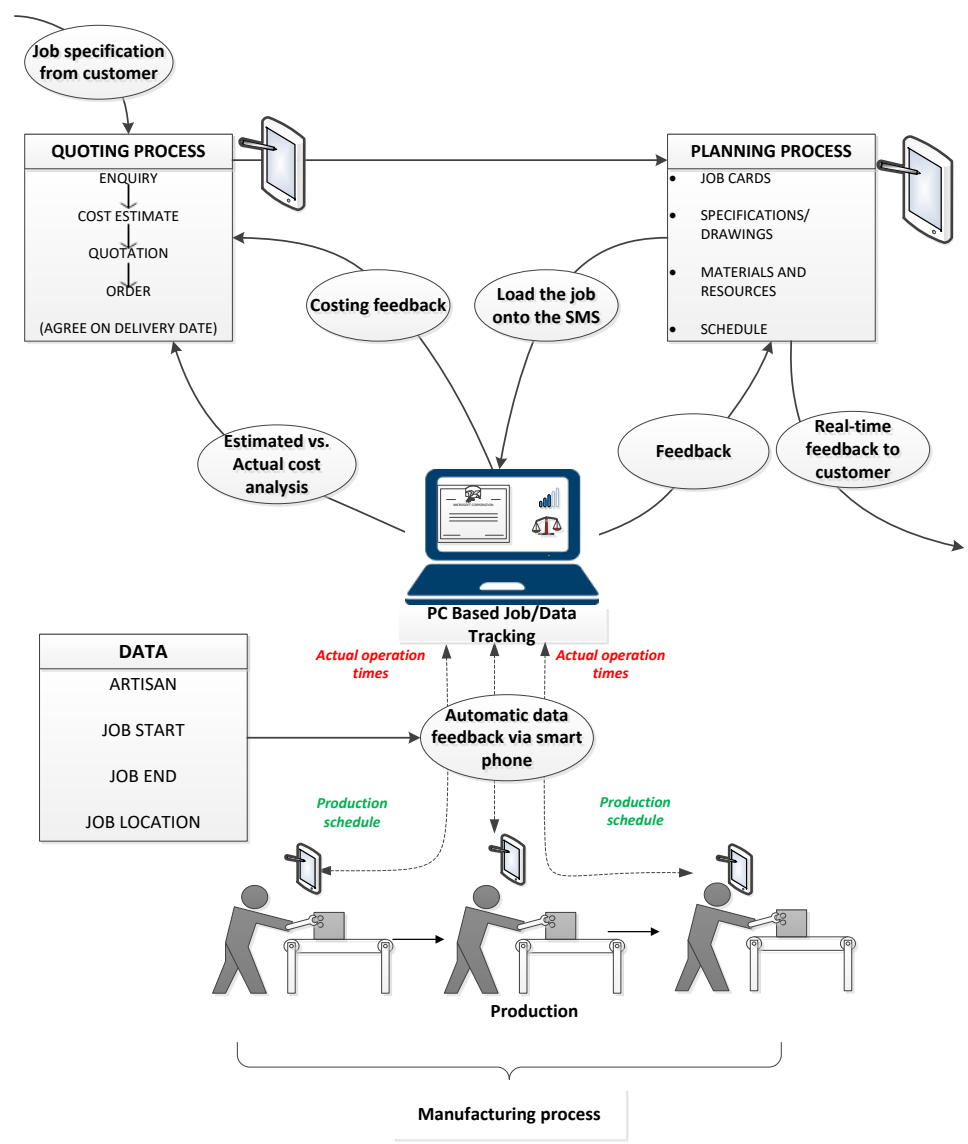

Figure 6: Schematic diagram of SMS overview

Table 4: Software and hardware requirements

\begin{tabular}{|c|c|c|c|}
\hline Question & $\begin{array}{l}\text { Summary of responses } \\
\text { from experts }\end{array}$ & Software implications & Hardware implications \\
\hline $\begin{array}{l}\text { Integration with existing } \\
\text { data management } \\
\text { platforms }\end{array}$ & $\begin{array}{l}\text { Yes. } \\
\text { Some firms already use } \\
\text { Excel and Pastel for data } \\
\text { management. }\end{array}$ & $\begin{array}{l}\text { The selected software } \\
\text { platform should be } \\
\text { compatible with many } \\
\text { platforms, especially } \\
\text { Microsoft Excel. }\end{array}$ & $\begin{array}{l}\text { The selected device } \\
\text { must be compatible } \\
\text { with the software } \\
\text { platform chosen. }\end{array}$ \\
\hline $\begin{array}{l}\text { Ability to take photos, } \\
\text { graphics, or video }\end{array}$ & $\begin{array}{l}\text { Yes. } \\
\text { During the order } \\
\text { definition stage, there } \\
\text { may be a need to take a } \\
\text { photo of the sample } \\
\text { product or part. In some } \\
\text { cases, toolmakers may } \\
\text { need to take a video of } \\
\text { the process on a machine. }\end{array}$ & $\begin{array}{l}\text { The selected software } \\
\text { platform should } \\
\text { support capturing and } \\
\text { storage of pictures and } \\
\text { videos in the dataset. }\end{array}$ & $\begin{array}{l}\text { The selected devices } \\
\text { should have built-in } \\
\text { cameras for taking } \\
\text { photos and videos. They } \\
\text { should also have the } \\
\text { capability, and a large } \\
\text { enough screen, to } \\
\text { display graphics and } \\
\text { videos. }\end{array}$ \\
\hline Need to record GPS data & No & None & None \\
\hline $\begin{array}{l}\text { Need to collect data } \\
\text { from the field }\end{array}$ & $\begin{array}{l}\text { Yes. } \\
\text { The engineering drawing } \\
\text { is also supposed to be } \\
\text { captured during the } \\
\text { production process. }\end{array}$ & $\begin{array}{l}\text { The selected software } \\
\text { platform should } \\
\text { support the capturing } \\
\text { of PDF files for the } \\
\text { engineering drawings. }\end{array}$ & $\begin{array}{l}\text { The selected devices } \\
\text { should be able to } \\
\text { connect to either a } \\
\text { cellular or a wireless } \\
\text { network (Wi-Fi). }\end{array}$ \\
\hline
\end{tabular}


Table 4 (cont.): Software and hardware requirements

\begin{tabular}{|l|l|l|l|}
\hline Question & $\begin{array}{l}\text { Summary of responses } \\
\text { from experts }\end{array}$ & Software implications & Hardware implications \\
\hline $\begin{array}{l}\text { Complex filter logic in } \\
\text { data collection }\end{array}$ & $\begin{array}{l}\text { Yes } \\
\text { The logic for the cost } \\
\text { estimation and production } \\
\text { data collection processes } \\
\text { is complex. }\end{array}$ & $\begin{array}{l}\text { The selected software } \\
\text { platform should } \\
\text { support skip logic } \\
\text { during the } \\
\text { development phase. }\end{array}$ & $\begin{array}{l}\text { The selected devices } \\
\text { must have a reasonable } \\
\text { amount of processing } \\
\text { power. }\end{array}$ \\
\hline $\begin{array}{l}\text { Need for external } \\
\text { support during } \\
\text { development }\end{array}$ & $\begin{array}{l}\text { Yes. } \\
\text { The researcher and } \\
\text { respondents conducting or } \\
\text { participating in the study } \\
\text { are not software } \\
\text { developers, so will need } \\
\text { help during the } \\
\text { development phase. }\end{array}$ & $\begin{array}{l}\text { The sected software } \\
\text { dedicated support } \\
\text { service (or community) } \\
\text { that will assist in the } \\
\text { development phase. }\end{array}$ & $\begin{array}{l}\text { None (software-red } \\
\text { question) }\end{array}$ \\
\hline $\begin{array}{l}\text { Need for merging with } \\
\text { external data sets }\end{array}$ & $\begin{array}{l}\text { Yes. } \\
\text { There is a need to } \\
\text { integrate the collected } \\
\text { data with financial } \\
\text { systems in the future. }\end{array}$ & $\begin{array}{l}\text { The selected software } \\
\text { platform should be } \\
\text { compatible with } \\
\text { existing data sets. }\end{array}$ & $\begin{array}{l}\text { None (software-related } \\
\text { question) }\end{array}$ \\
\hline
\end{tabular}

\subsection{SMS module navigation}

The developed SMS is a web-based mobile solution, as shown in the design specification overview in Figure 6 . The mobile solution has five different sub-modules that were deployed in different parts of a tooling firm. Figure 7 shows the main switchboard for the system. Each user obtained only the module relevant to their operations.



Dashboard

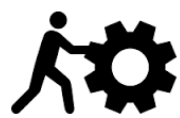

Production

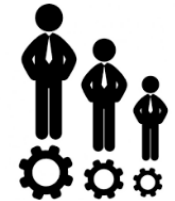

Resources

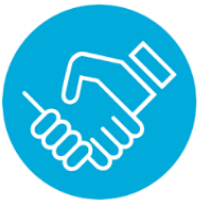

Sales

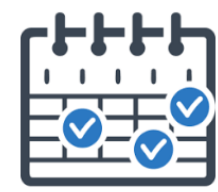

Scheduling

Figure 7: Shop-floor management system (SMS) main switchboard modules

The resources module is used to prepare the system by recording all of the company's resources, which include worker details, machines, and assets. The users can also define common disturbances experienced and daily operations conducted. These are also used by other modules of the system during the quoting, planning, and production phases. This part (the resources module) is specifically deployed and made available to the human resources department of the business.

The navigation flowchart for the resources module is illustrated in Figure 8 below.

The sales module is deployed to the sales and cost estimation teams of the tooling business. The module allows for customer details and job specifications for each order or job to be captured after a customer's enquiry. Upon receipt of an enquiry, the cost estimators determine the price of the job through parametric entry of the operations, materials, and services rendered per order. Upon completion of the costing, automated emails are generated and sent to the client with details of the quoted prices and the terms. This process significantly reduces the time spent on other administrative duties, such as generating quotes and invoices.

The navigation flowchart for the sales module is illustrated in Figure 9 below. A common trend in the tooling business derived during the analysis was that of repeat orders occurring in the future. Due to this trend, the system also allows for the duplication of an old order so that the cost estimation process is not repeated. Upon approval by the customer, the order details are made available to the scheduling module of the system. 


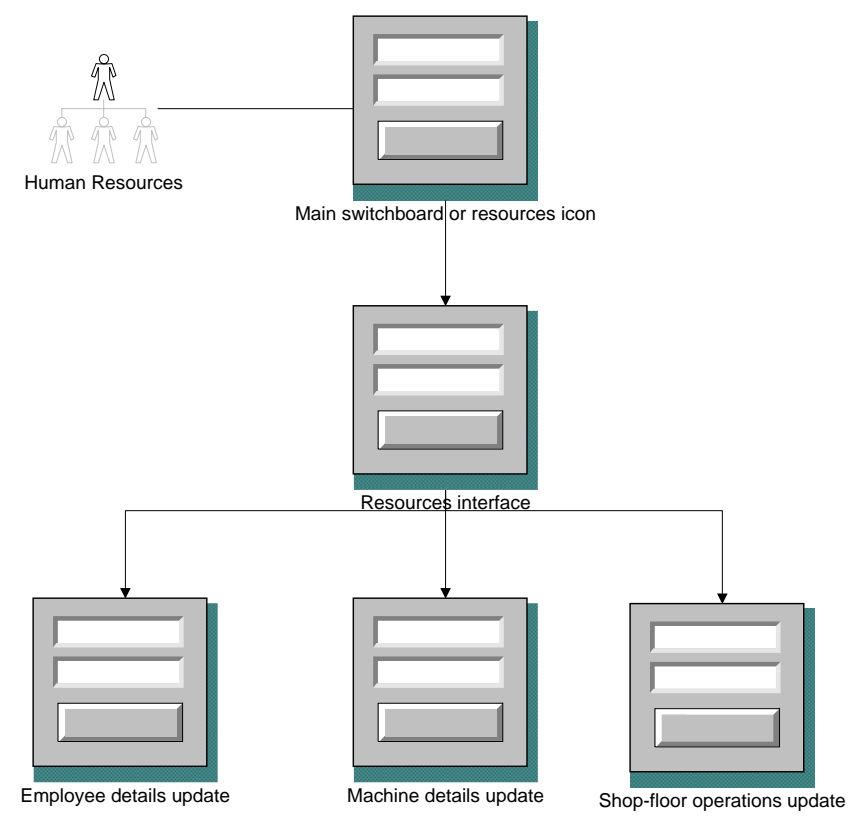

Figure 8: Resources module navigation flowchart

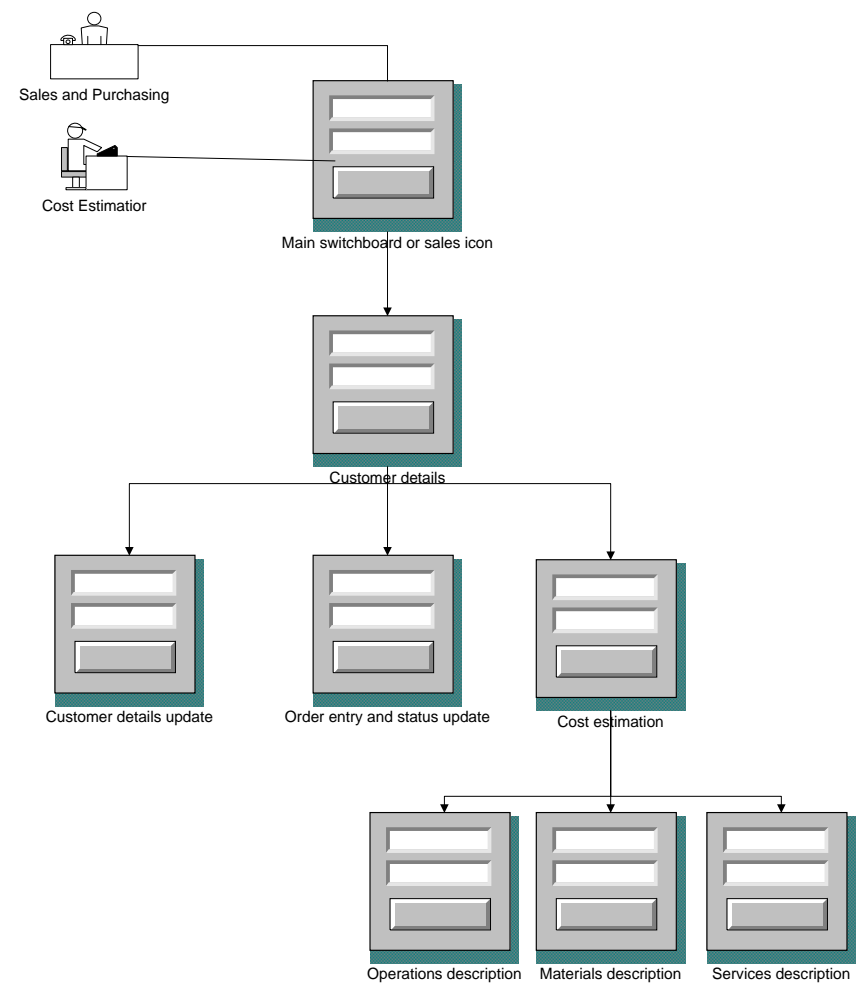

Figure 9: Sales module navigation flowchart

In the world of tooling, cost estimation is one of the most complex tasks; it requires expert knowledge for an accurate quote to be generated. Thus the system employs intelligent algorithms to derive certain costing parameters. The pseudo-code shown in Figure 10 illustrates the decisionmaking algorithm employed by the system during the estimation process: 
BEGIN (Cost estimation interface)

SELECT required operation;

FOR selected operation(s):

Find the required relevant machine and operator;

Automatically display the machine and operator rate;

Automatically compute operation cost

End loop;

SELECT required material(s);

FOR selected material(s):

Find unit material cost;

Automatically display the unit cost and use quantity defined to compute material cost;

End loop;

If required: SELECT service(s) required;

FOR selected service(s):

Find, display and compute service cost;

End loop;

Compute total operational cost and save;

Send automated emails to client and cost estimator;

END

Figure 10: Pseudo-code for decision-making intelligence during estimation

Process planners or project managers can access all approved jobs from the scheduling module. In this platform, raw material purchases from suppliers are also facilitated. After the materials are received, tasks are assigned to the shop-floor toolmakers. Once deployed, each toolmaker can view the tasks assigned to them via the production module. The navigation flowchart for the scheduling module is illustrated in Figure 11 below.

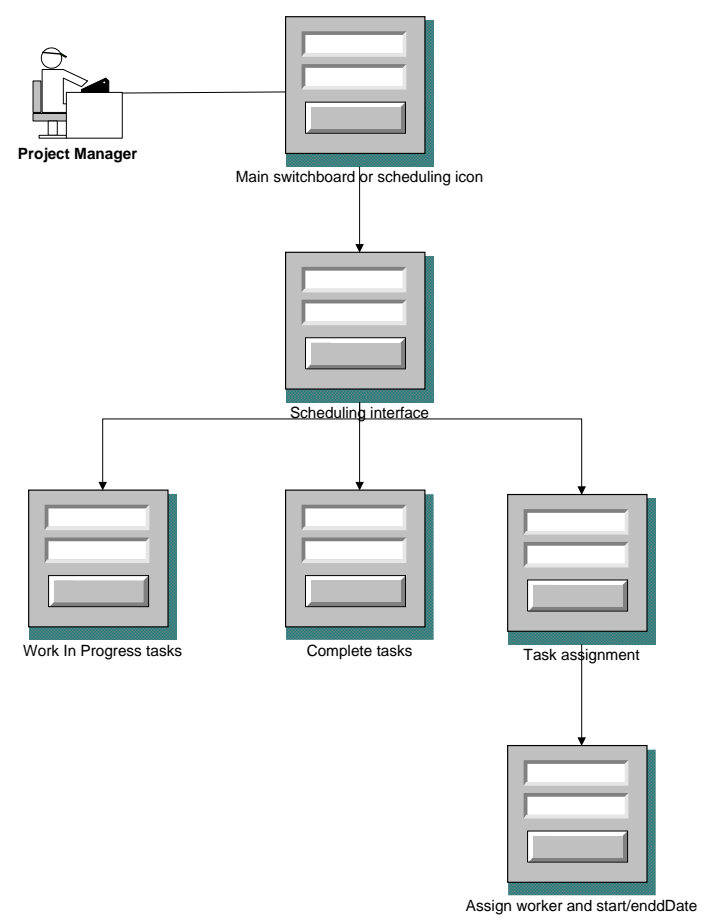

Figure 11: Scheduling module navigation flowchart

The production module is specifically deployed to the workers on the shop floor for the time-based entry and accounting of tasks done. In real time, workers can enter the start and stop times for their jobs. Workers can also input data on any recurring disturbances occurring during production. Once disturbances are recorded, the managers receive triggers of the event via email. Figure 12 below illustrates the production module navigation flow chart. 




Figure 12: Production module navigation flowchart

The dashboard module of the system is deployed to the top management only. The platform facilitates the real-time monitoring of shop-floor activities on key performance order-related indicators, which include due date conformance and order percentage progress. The managers can also view, in real time, costing analytics such as actual cost incurred versus estimated cost, labour hours per employee, and machine run times. The navigation flowchart for the dashboard module is illustrated in Figure 13 below. Although this is the main part that top management uses to observe shop-floor events, they requested to have access to the other four modules as well.

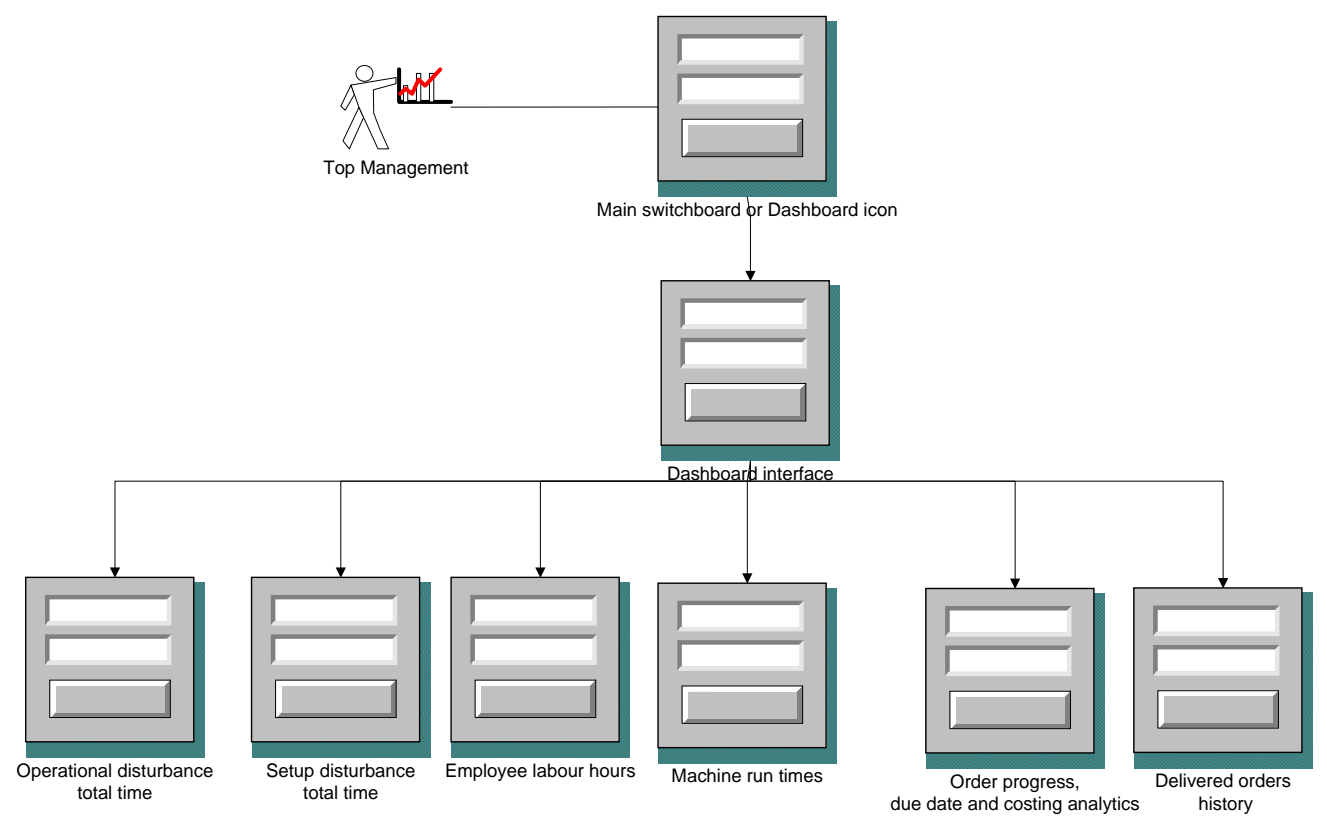

Figure 13: Dashboard navigation flowchart 
The shop-floor management system (SMS) developed here is unique in addressing the requirements of South African TDM firms, which include:

- Interfacing shop-floor workers with tool-room managers;

- $\quad$ Real-time shop-floor data collection by toolmakers;

- $\quad$ Distributed information sharing in a tool-room environment;

- Generation of order progress reports;

- Information storage of order histories;

- $\quad$ Automated computation of actual costs incurred;

- $\quad$ Automated reporting and email functions; and

- $\quad$ Cost analytics of estimated vs actual costs per job.

The developed SMS application was only implemented within one company. However, since the tool is a distributed system using mobile devices, future work can be conducted on extending the application to the domain of TDM customers and suppliers. In that way, customers will be able to enter their requirements and request quotations, while suppliers can consistently communicate about the services and products they supply (with current updated prices). Thus future work can also be done in deploying the application to TDM customers and suppliers. Furthermore, according to Christensen [50], the introduction of new technologies to improve business operations brings in some "disruptive characteristics". All new technologies can have negative implications, especially during the introduction phases. Since the SMS is a web-based solution, threats associated with the internet are a possibility, and the absence of a good network can affect functionality. Therefore, further work can also be conducted in investigating all the disruptive characteristics of implementing the SMS in a South African tooling environment. Such an effort will help to fine-tune the solution to improve its operational effectiveness.

\section{REFERENCES}

[1] Malherbe, D.C. 2007. Benchmarking in the South African tool and die manufacturing industry (Masters thesis, Stellenbosch University, South Africa). Retrieved August 13, 2013 from http://scholar.sun.ac.za/handle/10019.1/2121.

[2] Henriques, E. \& Pecas, P. 2013. New business models for the tooling industry. Journal of Current Issues in Finance, Business and Economics, 6(2), p.100.

[3] Geyer, J. \& Bruwer, R. 2006. Role of collaboration in the South African tooling industry. Journal of New Generation Sciences, 4(1), pp. 64-71.

[4] Schuh, G., Pitsch, M., Komorek, N., Schippers, M. \& Salmen, M. 2014. Cutting manufacturing failure costs in the tool and die industry by implementing a knowledge transfer system to avoid and correct mistakes more effectively. Procedia CIRP, 16, pp. 80-85.

[5] Schuh, G. 2011. Toolmaking for the future: A global study of today's situation and future trends in the tooling industry, Laboratory for Machine Tools and Production Engineering of RWTH, pp. 1-36.

[6] Choi, Y., Shin, J., Choi, H. \& Lee, S. 2010. Quality management system for web-based collaboration in mold \& die industry. Proceedings of 40th International Conference on Computers and Industrial Engineering: Soft computing techniques for advanced manufacturing and service systems, pp. 1-6. Awaji, Japan: Institute of Electronics and Electrical Engineers.

[7] Schuh, G., Pitsch, M., Kuhlmann, T. \& Stark, M. 2016. World of tooling. Proceedings of International Conference on Competitive Manufacturing 16, pp. 57-62. Stellenbosch, South Africa.

[8] Dewa, M.T., van der Merwe, A.F. \& Matope, S. 2015. Towards a competitive South African tooling industry. International Journal of Social, Behavioral, Educational, Economic, Business and Industrial Engineering, 9(11), pp. 3524-3529. Retrieved January 10, 2016, from http: / / waset.org/publications/10002156/towards-a-competitive-south-african-tooling-industry.

[9] Von Leipzig, K. \& Dimitrov, D. 2015. Cluster development in the SA tooling industry. The South African Journal of Industrial Engineering, 26(3), pp. 110-124.

[10] Schuh, G., Pitsch, M., Salmen, M. \& Rittstieg, F. 2016. Fast forward tooling. Proceedings of International Conference on Competitive Manufacturing 16, pp. 63-70. Stellenbosch, South Africa.

[11] Schuh, G., Boos, W., Pitsch, M., Salmen, M., Hensen, T., Kuhlmann, T. \& Rittstieg, F. 2015. Fast forward tooling, pp. 40-43. Laboratory for Machine Tools and Production Engineering (WZL).

[12] Samuelson, N., Lanman, C. \& Pocek, C. 2015. Internet of Things: New challenges and opportunities for semiconductor supply chain, pp. 1-4, Retrieved 2 May, 2016, from: https: / / legacy.alixpartners.com/en/LinkClick.aspx?fileticket=Ddm2RT9_FHw\%3d\&tabid=635. 
[13] Schuh, G., Kuhlmann, K., Pitsch, M. \& Komorek, N. 2013. Digitalization as a key enabler for efficient value creation networks in the tool and die making industry. Proceedings of Portland International Conference on Management of Engineering and Technology. Technology Management in the IT-Driven Services, pp. 1976-1984. [CD] San Jose, California, USA, IEEE/ Portland International Center for Machining.

[14] Oesterreich, T.D. \& Teuteberg, F. 2016. Understanding the implications of digitisation and automation in the context of Industry 4.0: A triangulation approach and elements of a research agenda for the construction industry. Computers in Industry, 83, pp. 121-139.

[15] Stolterman, E. \& Fors, A.C. 2004. Information technology and the good life. Information Systems Research, 143, pp. 687-692.

[16] Parviainen, P., Tihinen, M., Kääriäinen, J. \& Teppola, S. 2017. Tackling the digitalization challenge: How to benefit from digitalization in practice. International Journal of Information Systems and Project Management, 5(1), pp. 63-77.

[17] Brennen, S. \& Kreiss, D. 2014. Digitalization and digitization. Retrieved September 12, 2017 from http: / / culturedigitally.org/2014/09/digitalization-and-digitization/.

[18] Park, J. 2015. Evaluating a mobile data-collection system for production information in SMEs. Computers in Industry, 68, pp. 53-64.

[19] Henriette, E., Feki, M. \& Boughzala, I. 2015. The shape of digital transformation: A systematic literature review. Proceedings of Mediterranean Conference on Information Systems (MCIS), pp. 1-13. Samos, Greece: Association for Information Systems.

[20] Reinhard, G., Jesper, V. \& Stefan, S. 2016. Industry 4.0: Building the digital enterprise. 2016 Global Industry 4.0 Survey, pp. 1-39.

[21] Satyavolu, P., Setlur, B., Thomas, P. \& lyer, G. 2015. Designing for manufacturing's “Internet of Things". Technology solutions, pp. 4-14. Retrieved November 21, 2016 from https://www.cognizant.com/whitepapers/Designing-for-Manufacturings-Internet-of-Things.pdf.

[22] Stancioiu, A. 2017. The fourth industrial revolution: Industry 4.0. Fiability \& Durability / Fiabilitate si Durabilitate, 1, pp. 74-78. Retrieved January 16, 2018 from http: / / web.b.ebscohost.com/ehost/detail/detail?vid=0\&sid=76125aa0-d343-498c8bab26c4c3ab2a20\%40sessionmgr101\&bdata=JnNpdGU9ZWhvc3QtbGI2ZQ\%3D\%3D\#AN=123300383\&db=aph.

[23] Brettel, M., Friederichsen, N., Keller, M. \& Rosenberg, M. 2014. How virtualization, decentralization and network building change the manufacturing landscape: An industry 4.0 perspective. Retrieved August 10 , 2017, from https://www.scribd.com/document/316635938/How-Virtualization-Decentralization-andNetwork-Building-Change-the-Manufacturing-Landscape-an-Industry-40-Perspective.

[24] Zawadzki, P. \& Żywicki, K. 2016. Smart product design and production control for effective mass customization in the Industry 4.0 concept. Management and Production Engineering Review, 7(3), pp. 105112.

[25] Krishnan, A., Pujari, G. \& Sarkar, N. 2015. A framework to speed manufacturing's digital business transformation, pp. 1-17, Retrieved 2 January, 2017 from:

https: / /www.cognizant.com/InsightsWhitepapers/a-framework-for-digital-business-transformationcodex-1048.pdf.

[26] Iwaya, L.H. 2016. Secure and privacy-aware data collection and processing in mobile health systems (Doctoral dissertation, Karlsstad Universitet, Sweden). Retrieved October 13, 2017 from http://www.divaportal.org/smash/record.jsf?pid=diva2\%3A1043735\&dswid=_vpx=hZWWCedGvRH2.

[27] Richter, A. 2017. IT on the shop floor - Challenges of the digitalization of manufacturing companies. In 30th BLED eConference, Digital Transformation - From Connecting Things to Transforming Our Lives, pp. 1-16.

[28] Ebner, G. \& Bechtold, J. 2012. Are manufacturing companies ready to go digital? Capgemini Consulting Group, pp. 1-15. Retrieved May 25, 2016 from https://www.capgemini.com/resource-fileaccess/resource/pdf/Are_Manufacturing_Companies_Ready_to_Go_Digital_.pdf.

[29] Nevo, S. \& Chengalur-Smith, I. 2017. Examining organizations' continued use of open source technologies. Information Technology \& People, 30(1), pp. 24-46.

[30] Upasani, O.S. 2016. Advantages and limitations of open source software for library management system functions: The experience of libraries in India. The Serials Librarian, 71(2), pp. 121-130.

[31] Trucano, M. 2014. Using mobile phones in data collection: Opportunities, issues and challenges. [Online], Retrieved September 10, 2015 from: $\quad$ http://blogs.worldbank.org/edutech/using-mobile-phonesdata-collection-opportunities-issues-and-challenge.

[32] Vieira, D. \& Vieira, D. 2015. Empowering mobile users: Applications in mobile data collection. MOBILITY 2014 : The Fourth International Conference on Mobile Services, Resources, and Users, pp. 56-60.

[33] Jung, C. 2011. Mobile data collection systems - A review of the current state of the field. Retrieved April 12, 2016 from http://humanitarian-nomad.org/mdc-research/.

[34] Satterlee, E., McCullough, L., Dawson, M. \& Cheung, K. 2015. Paper-to-mobile data collection: A manual. Retrieved August 28, 2016 from

https://www.fhi360.org/sites/default/files/media/documents/Paper_to_Mobile_Data_Collection_Manual 1.0.pdf.

[35] Mell, P. \& Grance, T. 2011. The NSIT definition of cloud computing: Recommendations of the National Institute of Standards and Technology. Retrieved July 15, 2014 from http: / / faculty. winthrop.edu/domanm/csci411/Handouts/NIST.pdf. 
[36] Carretero, J. \& Blas, J.G. 2014. Introduction to cloud computing: Platforms and solutions. Cluster Computing, 17(4), pp. 1225-1229.

[37] Jennings, R. 2009. Cloud computing with the Windows Azure platform. Retrieved September 12, 2013 from http:/ / lib.myilibrary.com.ez.sun.ac.za/Open.aspx?id=230684.

[38] Shroff, G. 2010. Enterprise cloud computing: Technology, architecture, applications. Cambridge, UK: Cambridge University Press.

[39] Hung, M.H., Lin, Y.C., Quoc Huy, T., Yang, H.C. \& Cheng, F.T. 2012. Development of a cloud-computingbased equipment monitoring system for machine tool industry. Proceedings of International Conference on Automation Science and Engineering, pp. 962-967.

[40] Hu, Y., Zhou, X. \& Li, C. 2010. Internet-based intelligent service-oriented system architecture for collaborative product development. International Journal of Computer Integrated Manufacturing, pp. 113125.

[41] Silva, C., Roque, L. \& Almeida, A. 2006. MAPP - A web-based decision support system for the mould industry. Decision Support Systems, 42, pp. 999-1014.

[42] Li, M., Wang, J., San, Y. \& Seng, K. 2005. A collaborative application portal for the mould industry. International Journal of Production Economics, 96, pp. 233-247.

[43] Hoefler, B.G. \& Mar, B.W. 1992. Systems-engineering methodology for engineering planning applications. Journal of Professional Issues in Engineering Education and Practice, 118(2), pp. 113-128.

[44] Spataru, A.C. 2010. Agile development methods for mobile applications (Masters thesis, University of Edinburgh, Scotland). Retrieved February 14, 2017 from: https://www.inf.ed.ac.uk/publications/thesis/online/IM100767.pdf.

[45] Dewa, M.T., van der Merwe, A.F., Matope, S. \& Nyanga, L. 2016. Decision support heuristics for cost estimation model of injection moulds. Proceedings of 27th SAIIE Conference, pp. 163-175. Stonehenge, North West: South African Institute for Industrial Engineering.

[46] Fonseca, M.J., Henriques, E., Ferreira, A. \& Jorge, J. 2007. Assisting mould quotation through retrieval of similar data. Digital Enterprise Technology, pp. 527-534.

[47] Duverlie, P. \& Castelain, J.M. 1999. Cost estimation during design step: Parametric method versus case based reasoning method. The International Journal of Advanced Manufacturing Technology, 15(12), pp. 895-906.

[48] Denkena, B., Lorenzen, L.E. \& Schürmeyer, J. 2009. Rule-based quotation costing of pressure die casting moulds. Production Engineering, 3(1), pp. 87-94.

[49] Dewa, M.T., van der Merwe, A.F. \& Matope, S. 2016. A holonic approach to reactive scheduling when rush orders emerge. Proceedings of International Conference on Competitive Manufacturing 16, pp. 337341. Stellenbosch, South Africa.

[50] Christensen, C.M. 1997. The innovator's dilemma: When new technologies cause great firms to fail. Boston, MA: Havard Business School Press. 